\title{
POLA-POLA KOMUNIKASI DALAM INTERAKSI JUAL BELI DI PASAR LOAK "BLOK M" JEMBER
}

\author{
COMMUNICATIVE STRATEGIES BETWEEN BUYERS AND SELLERS \\ AT "BLOK M" FLEA MARKET IN JEMBER
}

\author{
Siti Fatima ${ }^{1}$, Andang Subaharianto ${ }^{2}$, Edy Hariyadi ${ }^{3 *}$ \\ ${ }^{1}$ Alumni Fakultas Ilmu Budaya, Universitas Jember \\ ${ }^{2,3}$ Fakultas Ilmu Budaya, Universitas Jember \\ *Corresponding Author: edy.hariyadi@gmail.com \\ Informasi Artikel:
}

Dikirim: 29/7/2018; Direvisi: 4/9/2018; Diterima: 5/11/2018

\begin{abstract}
This research observes the communication patterns in the buying and selling interactions that occur between buyers and sellers at the "Blok M" flea market in Jember. The object of research is focused on used book sellers, and used clothing sellers (babebo). The purpose of this study is to describe the communication patterns that are formed through the process of interaction and reveal the cultural themes contained in the buying and selling interaction activities between sellers and buyers in the Jember "Blok $M$ " flea market. To achieve the research objectives ethnographic analysis of the James $P$. Spradley model is used which includes domain analysis, taxonomic analysis, compound analysis, and cultural themes. The results is in the buying and selling interactions in the Jember "Blok $M$ " flea market, active sellers direct the interaction and passive buyers in responding to the point of the conversation. In buying and selling transactions with buyers, the services provided by used booksellers are very fast and the tempo of interaction used by sellers is very short. Perlokusi utterances made by used book sellers are done as an effort to establish good relations with buyers. If the relationship can be established more closely then the buyer will feel satisfied (satisfy) and will remain a customer. The cultural theme in the process of economic transactions between used book sellers and buyers is the establishment of socio-emotional ties in order to strengthen relations and mutual respect to help long-term economic cooperation.
\end{abstract}

Keywords: buying and selling, communication patterns, ethnography of communication, Jember fleamarket, social action

\footnotetext{
Abstrak

Penelitian ini mengamati pola komunikasi dalam interaksi jual beli yang terjadi antara pembeli dan penjual di pasar loak "Blok M" di Jember. Objek penelitian difokuskan pada penjual buku bekas. Tujuan penelitian ini mendeskripsikan pola komunikasi yang terbentuk melalui proses interaksi dan mengungkap tema budaya yang terkandung dalam kegiatan interaksi jual beli antara penjual dan pembeli di pasar loak "Blok M" Jember. Untuk mencapai tujuan penelitian, analisis etnografi dari model James P. Spradley digunakan yang mencakup analisis domain, analisis taksonomi, analisis komponensial, dan tema budaya. Hasilnya adalah interaksi jual beli di pasar loak "Blok M" Jember, penjual aktif mengarahkan interaksi dan pembeli pasif dalam menanggapi pokok pembicaraan. Dalam transaksi jual beli dengan pembeli, layanan yang diberikan oleh penjual buku bekas sangat cepat dan tempo interaksi yang digunakan oleh penjual sangat
} 
singkat. Tuturan perlokusi yang dilakukan oleh penjual buku bekas dilakukan sebagai upaya menjalin hubungan baik dengan pembeli. Jika hubungan dapat terjalin lebih erat, pembeli akan merasa puas (satisfy) dan akan tetap menjadi pelanggan. Tema budaya dalam proses transaksi ekonomi antara penjual buku bekas dan pembeli adalah pembentukan ikatan sosial-emosional untuk memperkuat hubungan dan saling menghormati untuk membantu kerja sama ekonomi jangka panjang.

Kata kunci: jual beli, pola komunikasi, etnografi komunikasi, pasar loak Jember, tindakan sosial

\section{PENDAHULUAN}

Komunikasi adalah proses pertukaran informasi antarindividu melalui sistem simbol, tanda, atau tingkah laku yang umum. Proses komunikasi harus memiliki tiga komponen yaitu: (1) pihak yang berkomunikasi, yakni pengirim (sender) dan penerima (receiver) informasi yang diinformasikan, yang lazim disebut partisipan; (2) informasi yang dikomunikasikan seperti gagasan, ide, keterangan, atau pesan; dan (3) alat yang digunakan dalam komunikasi (verbal dan nonverbal) (Chaer dan Agustina, 2010:17). Proses komunikasi dilaksanakan secara sadar, aktif, dan timbal-balik. Komunikasi dapat juga berlangsung baik secara searah seperti dalam khotbah di masjid, maupun dua arah seperti transaksi jual-beli di pasar.

Penyampaian pesan atau komunikasi antara penutur dan lawan tutur dapat terjalin dengan baik apabila tiga syarat komponen tersebut terpenuhi. Selain ketiga komponen tersebut juga terdapat salah satu syarat berkomunikasi dengan baik yaitu kesantunan dalam menggunakan bahasa yang akan disampaikan penutur kepada lawan tutur agar tidak terjadi kesalahpahaman. Lakoff (dalam Chaer dan Agustina, 2010:46) menjelaskan bahwa sebuah tuturan dapat dikatakan santun apabila ia tidak terdengar memaksa atau angkuh, tuturan itu memberi pilihan kepada lawan tutur, dan lawan tutur merasa senang.

Chaer dan Agustina (2010:9) juga berpendapat bahwa dalam kegiatan pertuturan tersebut sebaiknya isi tuturan disampaikan secara santun karena pertuturan yang disampaikan secara tidak santun dapat menampar dan mengancam muka lawan tutur. Kesopanan dalam berbahasa merupakan salah satu syarat utama dalam menyampaikan pesan kepada lawan tutur agar terjalin suatu keharmonisan. Bahasa merupakan salah satu alat komunikasi sehari-hari yang digunakan manusia untuk mengekspresikan pikiran dan perasaannya.

Penelitian ini dilakukan dengan mengamati pola komunikasi yang berlangsung dalam interaksi jual beli yang terjadi antara pembeli dan penjual di pasar loak "Blok M" di Jember. Di pasar loak "Blok M" terdapat lapak buku bekas, baju bekas (babebo), helm, onderdil sepeda motor, alat elektronika, sepeda, sepatu, dan lain-lain. Objek penelitian difokuskan pada lapak buku bekas. Dalam proses komunikasi tersebut terdapat proses tawar-menawar atau yang menurut antropolog yaitu harga luncur (sliding price system).

Di pasar loak "Blok M", sekitar 75\% buku yang dijual di toko buku Toga Mas dan Gramedia Jember tersedia pula di lapak penjual buku yang ada di pasar loak ini. Di lapak buku bekas tersedia buku bekas dan buku baru, harga yang diberikan sangat murah karena penjual memberikan potongan harga untuk jenis buku baru.

Perbandingan dengan toko buku Toga Mas dan Gramedia selisih harganya sangat jauh. Walaupun lebih murah tetapi kualitas buku yang dijual di lapak buku pasar loak "Blok M" sama dengan kualitas yang ada di toko buku Toga Mas dan Gramedia. Oleh karena itu, 
pembeli terkadang lebih berminat untuk berbelanja buku di pasar loak karena harganya lebih terjangkau dibandingankan dengan harga di Toga Mas atau pun Gramedia.

Penelitian dilakukan di pasar loak yang berada di sepanjang jalan di belakang Matahari Mall Jember yang dikenal masyarakat dengan sebutan pasar loak "Blok M'. Penamaan "Blok M" mungkin diasosiasikan secara kelakar dengan nama pasar terkenal di Jakarta yaitu Blok M, sebuah plesetan untuk menyingkat lokasi pasar loak tersebut yaitu "belakang Matahari".

Penelitian ini menggunakan pendekatan etnografi komunikasi. Pada penelitian ini digunakan teori interaksionisme simbolik untuk mengetahui penggunaan bahasa dan makna yang tersurat pada interaksi pelayanan pelanggan yaitu adanya stimulasi yang diterima dan respon yang terjadi melalui simbol-simbol yang mereka ciptakan berdasarkan realitas sosial.

Simbol komunikasi merupakan proses dua arah di mana kedua pihak memberikan makna atau arti terhadap simbol-simbol itu. Menurut Littlejohn dan Foss (2009:231), interaksionisme simbolik berfokus pada cara-cara manusia membentuk makna dan proses stimulasi respon dalam masyarakat melalui percakapan.

Berdasarkan latar belakang di atas, permasalahan dalam penelitian ini dirumuskan sebagai berikut. Bagaimanakah bentuk pola-pola komunikasi, proses, dan makna dalam interaksi jual beli buku bekas antara penjual buku bekas dengan pembeli?

Secara umum tujuan penelitian ini adalah untuk mendeskripsikan interaksi komunikatif antara penjual dan pembeli di Pasar Loak Kabupaten Jember. Secara spesifik, tujuan penelitian ini dirumuskan sebagai berikut: mendeskripsikan bentuk pola-pola komunikasi, proses dan makna dalam interaksi jual beli buku bekas antara penjual buku bekas dengan pembeli.

Beberapa penelitian tentang strategi komunikasi telah banyak diteliti oleh peneliti sebelumnya yaitu: Wibowo (2015) dan Izzah (2014). Penelitian pertama, tentang pola komunikasi antara penjual dan pembeli oleh Wibowo (2015) berjudul "Pola Komunikasi antara Penjual dan Pembeli di Pasar Kalipait Kecamatan Tegal Dlimo Kabupaten Banyuwangi (Kajian Etnografi Komunikasi)". Penelitian Wibowo mendeskripsikan tentang interaksi komunikasi antara penjual dan pembeli dalam transaksi barang yang diperjualbelikan. Penelitian ini merupakan penelitian kualitatif dan menggunakan model analisis etnografi Spradley (1997) untuk mendeskripsikan proses-proses komunikasi antara penjual dan pembeli, pola-pola interaksi komunikasi yang terbentuk, dampak dari pola-pola interaksi komunikasi jual beli yang efektif, dan penemuan tema-tema budaya yang secara implisit terkandung dalam wacana interaksi. Selain itu, penelitian Wibowo juga memaparkan dengan rinci subjek dan objek penelitian. Objek penelitian adalah interaksi komunikasi antara penjual dan pembeli (masyarakat lokal) dalam transaksi jual beli di pasar Tegaldlimo Kabupaten Banyuwangi.

Fokus penelitian Wibowo adalah interaksi komunikatif berdasarkan aspek kedekatan antara penjual dan pembeli. Aspek yang dimaksud yaitu: (1) interaksi komunikatif antara penjual dan pembeli baru, dan (2) interaksi komunikatif antara penjual dan pembeli pelanggan. Dari dua aspek interaksi komunikatif di atas, Wibowo memaparkan adanya polapola komunikasi yang terbentuk dalam aktivitas jual beli dagangan antara penjual dan pembeli. Pola-pola tersebut sebagai berikut: (1) interaksi diawali dengan memilih barang atau 
langsung menyebut barang yang di maksud, (2) penggunaan simbol-simbol bahasa yang bersifat lugas dan struktur gramatika yang sederhana dapat saling memudahkan penjual dan pembeli, (3) komunikasi tatap muka dan dialogis memudahkan transaksi antara penjual dan pembeli. Melalui pemaparan tersebut, Wibowo kemudian merumuskan tema-tema budaya yang terkandung dalam wacana percakapan antara penjual dan pembeli dalam transaksi jual beli. Menurut Wibowo, tema budaya yang ditemukan adalah "Kejujuran yang melandasi sikap saling mempercayai dan saling menghargai merupakan syarat mendasar berlangsungnya kegiatan jual beli serta agar hubungan kerja antar personal (penjual dan pembeli) yang sudah terjalin baik tetap terjaga, stabil, dan berkelanjutan", Tema budaya tersebut menunjukkan bahwa transaksi jual beli antara penjual dan pembeli merupakan bagiaan dari praktik budaya masyarakat di sektor ekonomi pasar tradisional.

Penelitian kedua dari sebuah skripsi yang ditulis oleh Izzah (2014) yang berjudul "Interaksi Jual Beli Hasil Tangkapan Nelayan di Weru Kompleks Kecamatan Paciran Kabupaten Lamongan (Suatu Tinjauan Etnografi Komunikasi)". Penelitian tersebut membahas tentang interaksi jual beli hasil tangkapan nelayan di Weru Kompleks, Kecamatan Paciran, Kabupaten Lamongan. Interaksi jual beli antara penjual borongan dengan pembeli tengkulak dan antara penjual eceran dengan pembeli eceran memiliki pola dan variasi pola komunikasi yang berbeda. Pada penelitian tersebut digunakan pendekatan etnometologi untuk mendeskripsikan realitas sosial dalam bentuk interaksi jual beli, khususnya pada kebutuhan pangan yang dihasilkan oleh nelayan.

Pada tahap analisis data, peneliti menganalisis data tuturan interaksi percakapan yang terjadi antara penjual dan pembeli terhadap hasil tangkapan nelayan dengan menggunakan tiga tuturan, yakni tuturan pembuka, tuturan inti, dan tuturan penutup. Tuturan pembuka merupakan awal penjual menawarkan barang, tuturan isi merupakan inti pokok pertuturan tentang terjadinya proses tawar-menawar, dan tuturan penutup merupakan tuturan akhir sebagai penentuan apakah barang tersebut dilepas atau tidak. Proses interaksi jual beli yang terjadi pada kegiatan tawar-menawar anatara penjual yang memborongkan dengan pembeli tengkulak terjadi mulai dari dua sampai dengan sembilan kali struktur setelah terjadinya kesepakatan harga, sedangkan pergantian pembicaraan terjadi tiga sampai ke tiga belas kali. Kegiatan tawar-menawar antara penjual pengecer dengan pembeli eceran terjadi tiga sampai sembilan struktur setelah dilakukan kesepakatan harga. Kedua siklus interaksi jual beli antara penjual dan pembeli dianalisis dengan menggunakan tiga tuturan yakni tuturan pembuka, tuturan inti, serta tuturan penutup secara utuh.

\section{METODE}

Moleong (2016:6) menyatakan bahwa penelitian kualitatif adalah penelitian yang bermaksud untuk memahami fenomena tentang sesuatu yang dialami oleh subjek penelitian misalnya perilaku, persepsi, motivasi, tindakan, dan lain-lain. Metode penelitian kualitatif dipilih karena data dalam penelitian ini menguraikan kata-kata dari orang-orang dan perilaku yang diamati yaitu pola-pola komunikasi interaksi antara penjual dan pembeli di pasar loak Kabupaten Jember. Kata-kata tersebut berupa tuturan yang mengandung strategi komunikasi. Peneliti sebagai instrumen berhadapan langsung dengan objek penelitian dan juga melakukan observasi serta mencatat data. Data penelitian ini diambil dari fenomena kebahasaan yang 
terjadi secara alamiah yang tidak dimanipulasi, direncanakan, dan tidak dibuat-buat. Informasi yang diperoleh bersifat relevan sesuai dengan kenyataan yang ada.

Spradley (1997:5) mengemukakan inti dari etnografi adalah upaya memahami makna suatu tindakan sosial dari sekelompok orang yang diteliti. Pemahaman makna tersebut dapat diperoleh melalui tuturan bahasa atau perilaku sosial. Setiap masyarakat menggunakan sistem makna untuk mengatur tingkah laku, memahami diri sendiri atau orang lain, dan untuk memahami dunia di mana mereka hidup.

Berdasarkan jenis penelitian kualitatif di atas, penelitian ini adalah penelitian etnografi. Menurut Bungin (2007:94), penelitian etnografi adalah penelitian tentang cara hidup dan kegiatan sosial suatu kelompok masyarakat dalam kaitannya dengan unsur-unsur kebudayaan lainnya dan berdasarkan bahan-bahan keterangan tersebut dibuat deskripsi mengenai kebudayaan kelompok masyarakat tersebut. Tujuan penelitian etnografi adalah mendeskripsikan suatu kebudayaan atau unsur kebudayaan masyarakat dan memahami suatu pandangan hidup dari sudut pandang masyarakat yang bersangkutan.

Data adalah sekumpulan informasi yang diperoleh dari informan melalui observasi dan wawancara pada suatu objek penelitian. Sebagaimana dikatakan oleh Mukhtar (2013:99), data adalah segala sesuatu yang terjadi sebagai bukti yang ditemukan secara empiris melalui penelitian. Sesuatu data dan informasi yang diperoleh dari informan dapat diperkuat (dapat dipercaya kebenarannya, valid, dan reliable) dengan menggunakan teknik triangulasi. Secara umum, triangulasi merupakan pendekatan multimetode yang digunakan oleh peneliti pada saat mengumpulkan data. Ide dasar dari teknik triangulasi ini adalah fenomena sosial yang diteliti, dapat dipahami dengan baik sehingga diperoleh kebenarannya dari berbagai sudut pandang.

Berdasarkan sumbernya, dalam setiap penelitian terdapat dua data yang dibedakan tingkat signifikasinya, yaitu data utama (primer) dan data tambahan (sekunder). Menurut Lofland dan Lofland (dalam Moleong, 2016:112-115) sumber data utama (primer) dalam penelitian kualitatif adalah berupa kata-kata dan tindakan, kemudian data tambahan (sekunder) adalah sumber tertulis berupa dokumen pribadi, foto, dan sebagainya.

Menurut Afrizal (2015:138-143) ada dua kategori informan yaitu informan pengamat atau informan kunci (key informan) dan informan pelaku. Informan pengamat adalah informan yang memberikan informasi tentang orang-orang, suatu kejadian, atau suatu hal kepada peneliti. Informan disebut merupakan saksi suatu kejadian atau pengamat lokal, sedangkan informan pelaku adalah informan yang memberikan keterangan tentang dirinya: perilaku, pikiran, makna, dan pengetahuannya.

Metode pengumpulan data merupakan langkah yang paling penting untuk mendapatkan data. Data dikumpulkan oleh peneliti sendiri secara pribadi dengan memasuki lapangan. Hal ini dilakukan karena peneliti merupakan instrumen penelitian. Peneliti sendiri atau dengan bantuan orang lain merupakan alat untuk mengumpulkan data dan informasi dengan menggunakan metode penelitian yang meliputi: (1) introspeksi, (2) observasi partisipasi, dan (3) wawancara mendalam (Ibrahim, 1994:179-195). Di samping itu, pengumpulan data juga dilakukan dengan metode penelusuran dokumen. Data-data yang 
dikumpulkan berupa ucapan dan persepsi informan, tindakan simbolis, dokumen tertulis, dan foto.

Penelitian ditujukan untuk mengungkapkan makna perilaku sosial subjek penelitian secara akurat. Metode introspeksi digunakan untuk mengoreksi pemahaman tentang kebudayaan peneliti dan meneliti tentang mekanisme masyarakat memahami budayanya sendiri. Dalam penelitian etnografi, observasi partisipan digunakan peneliti untuk masuk ke dalam masyarakat yang akan ditelitinya (Kuswarno, 2008:48). Untuk menerapkan metode observasi partisipasi, peneliti harus membebaskan diri dari pengalaman kebudayaan peneliti sendiri. Dalam pelaksanaan observasi partisipasi, peneliti terlebih dahulu membangun hubungan lebih baik dan mendalam dengan informan (penjual, pembeli, dan pengelola pasar). Terjalinnya hubungan baik antara peneliti dan informan diharapkan mampu mewujudkan rasa saling percaya (rapport), sehingga informan tidak mencurigai peneliti sebagai orang yang hendak mencelakakannya (Bungin, 2007:95).

Wawancara merupakan suatu metode untuk mengorek informasi dari seorang informan. Jenis pertanyaan yang digunakan dalam wawancara merupakan pertanyaan yang berkaitan dengan pendapat. Jenis pertanyaan ini digunakan untuk mengetahui strategi komunikasi dan strategi kesantunan bahasa yang digunakan oleh penjual dan pembeli ketika sedang berinteraksi. Metode wawancara ini dilakukan kepada informan yang berkaitan dengan objek penelitian. Adapun informan yang dipilih adalah pembeli dan penjual di pasar loak "Blok M" di Kabupaten Jember.

Gejala sosial berupa fakta dan data tersimpan dalam bahan yang berbentuk dokumentasi. Dokumentasi adalah data-data tertulis atau gambar (foto) yang ada pada situasi sosial penelitian yang dikumpulkan sebagai penguat data observasi dan wawancara, serta sebagai pendukung dalam menulis laporan penelitian. Dalam penelitian ini, dokumentasi diperoleh dari arsip kegiatan interaksi jual beli yang dilakukan oleh penjual dan pembeli, arsip tersebut berupa foto kegiatan jual beli barang di pasar loak "Blok M" di Kabupaten Jember.

Data yang berhasil dikumpulkan melalui observasi partisipan dengan alat rekam, kemudian ditranskripsikan ke dalam data tertulis, kata-kata dalam data tersebut ditranskripsikan apa adanya sesuai dengan ucapan yang dikemukakan oleh subjek penelitian dan aturan ejaan yang diberlakukan dalam bahasa tersebut. Transkripsi data dalam penelitian ini berbentuk transkripsi ortografis. Adapun data yang berupa bahasa Jawa penulisannya mengikuti kamus bahasa Jawa (Mangunsuwito, 2014) dan data yang berupa bahasa Madura penulisannya mengikuti kamus bahasa Madura.

Secara umum, analisis merupakan suatu proses penemuan jawaban atas permasalahan dalam penelitian. Analisis data pada riset etnografi komunikasi dilakukan dengan cara menganalisis data lapangan yang dikumpulkan dari observasi partisipasi dan wawancara. Analisis data kualitatif (etnografi) pada dasarnya adalah ingin memahami situasi sosial (objek penelitian dalam penelitian kualitatif) menjadi bagian-bagian, hubungan antarbagian, dan hubungannya dengan keseluruhan (Sugiyono, 2016:116).

Analisis data adalah penetapan tahap-tahap dan langkah-langkah kegiatan terhadap informasi atau data yang sedang dan sudah dikumpulkan dengan tujuan untuk memperoleh kesimpulan penelitian (Hamidi, 2010:96). Kegiatan analisis data pada penelitian kualitatif dilakukan sejak pencarian data di lapangan sampai dengan penulisan laporan (Afrizal, 2015:176). Dalam penelitian ini digunakan metode analisis data sebagaimana yang diuraikan 
Spradley (1997:139-249) yaitu: (1) analisis domain; (2) analisis taksonomik; (3) analisis komponensial; dan (4) menemukan tema-tema budaya.

Analisis domain pada umumnya dilakukan untuk memperoleh gambaran yang umum dan menyeluruh tentang situasi sosial yang diteliti atau objek penelitian. Analisis domain merupakan langkah pertama dalam penelitian kualitatif etnografi. Ada tiga langkah persiapan analisis domain yaitu, (1) peneliti memilih situasi sosial (penjual sparepart, penjual kopi, penjual buku-buku bekas, penjual akik, penjual baju bekas); (2) melakukan observasi yakni mengamati simbol-simbol yang dipertukarkan dalam interaksi komunikatif antara penjual dan pembeli; (3) melakukan observasi deskriptif dengan pertanyaan grand-tour (situasi, aktor, waktu, aktivitas, dan tujuan) dan mini-tour (proses elaborasi terhadap subjek penelitian). Data diperoleh dari observasi, wawancara, dan dokumentasi. Hasilnya berupa gambaran umum tentang pasar loak "Blok M" di Kabupaten Jember melalui pertanyaan umum dan pertanyaan rinci, yang sebelumnya belum diketahui. Dalam analisis domain ini informasi yang diperoleh belum mendalam, masih di permukaan, namun sudah menemukan domain-domain atau kategori sosial yang diteliti (Spradley, 1997:159).

Dalam analisis domain, peneliti memahami situasi ranah sosial di Pasar Loak Kabupaten Jember. Pertama, banyaknya ranah sosial yang ada di pasar loak (toko barang pecah belah, toko kelontong, penjual helm, penjual akik, penjual buku-buku bekas, toko sepatu), peneliti pada akhirnya memilih salah satu ranah sosial atau objek penelitian yaitu lapak buku bekas dan babebo. Kedua, peneliti melalukan observasi atau pengamatan yang dilakukan dalam interaksi komunikatif antara penjual dan pembeli. Ketiga, peneliti melakukan observasi deskriptif dengan pertanyaan grand-tour (situasi, aktor, waktu, aktivitas, dan tujuan) dan mini-tour (proses elaborasi terhadap subjek penelitian). Peneliti memulai melakukan langkah awal wawancara dengan aktor atau penjual dan pembeli. Hasilnya berupa gambaran umum tentang pasar loak "Blok M" melalui pertanyaan umum dan pertanyaan rinci, yang sebelumnya belum diketahui. Dalam analisis domain ini informasi yang diperoleh belum mendalam, masih di permukaan, namun peneliti sudah menemukan domain-domain atau kategori sosial yang diteliti.

Setelah menentukan domian yang telah ditetapkan, selanjutnya peneliti melakukan analisis terfokus dengan melakukan penyelidikan bagaimana domain tersebut tersusun lebih rinci untuk menemukan pola, perilaku, budaya, kenyataan budaya, dan pengetahuan budaya (Mukhtar, 2013:125). Menurut Sugiyono (2016:110), analisis taksonomi adalah analisis terhadap keseluruhan data yang terkumpul berdasarkan domain yang telah ditetapkan. Sebagaimana dikatakan oleh Emzir (2010:210), analisis taksonomi (tacsonomi Analysis) dilakukan untuk menjabarkan domain-domain yang dipilih menjadi lebih rinci sehingga diketahui struktur internalnya dengan melakukan pengamatan yang lebih fokus.

Setelah melakukan analisis taksonomik, selanjutnya melakukan observasi terseleksi untuk melihat dan menemukan perbedaan yang ada dalam beberapa domain budaya. Kemudian melakukan analisis komponensial untuk mencari ciri pembeda atau yang kontras dari sub-sub kategori dari yang terkecil. Sebagaimana dikatakan oleh Emzir (2010:210) analisis komponensial adalah mencari ciri spesifik pada setiap struktur internal dengan cara 
mengontraskan antarelemen. Dengan teknik pengumpulan data yang bersifat triangulasi sejumlah dimensi yang spesifik dan berbeda pada setiap domain akan dapat ditemukan.

Penelitian ini memberikan porsi yang lebih pada suatu masyarakat yang diteliti untuk menafsirkan fenomena sosial yang terjadi dalam sebuah kelompok berdasarkan sudut pandang mereka. Penafsiran tersebut sangat penting untuk suatu kelompok penutur untuk mengorganisasi suatu aktivitas sosial. Hal itu sangat penting karena aktivitas sosial dapat membentuk suatu kebudayaan yang berlaku dalam suatu kelompok masyarakat.

Dalam suatu interaksi yang terjadi di kalangan masyarakat di kalangan pasar terkadang sering terjadi pengaplikasian suatu budaya yang lekat dalam lingkungan masyarakat. Di dalam suatu kelompok masyarakat yang melakukan interaksi sosial akan terlibat dalam runtutan tindakan atau perilaku yang berpola. Karena di dalam berinteraksi dalam lingkup pasar sekelompok masyarakat terlebih dahulu memahami suatu cara, tingkah laku dan kebiasaan sosial merupakan suatu manifestasi dari kebudayaan yang berlaku dalam suatu kelompok masyarakat. Karena di dalam sebuah interaksi yang terjadi di dalam lingkup pasar, masyarakat atau sekelompok penutur terlebih dahulu mengenal keadaan pasar tersebut.

Penelitian ini untuk menemukan tema-tema budaya dalam melakukan transaksi jual beli. Hal ini karena tema budaya yang berlaku dalam masyarakat pasar sangatlah penting untuk menjadi acuan dan ciri khas lingkungan pasar tersebut. Tema-tema budaya merupakan suatu pola sosial yang kompleks dalam suatu masyarakat dan menjadi ciri khas suatu anggota masyarakat tersebut (Spradley, 1997:25).

\section{HASIL DAN PEMBAHASAN}

Pola-pola komunikasi antara penjual buku bekas dan pembeli di pasar loak "Blok M" Jember, terbentuk melalui proses interaksi yang menunjang kelancaran transaksi kedua belah pihak. Proses jual beli yang terjadi di lapak buku-buku bekas di Pasar Loak merupakan jual beli musiman yaitu jual beli buku bekas akan ramai apabila terjadi di bulan-bulan awal tahun ajaran baru seperti masuknya anak-anak sekolah dari SD, SMP, SMA, dan juga mahasiswa. Jadi buku-buku yang diperjual-belikan tidak kalah dengan penjualan di Toko Buku Toga Mas dan Gramedia.

\section{Interaksi Komunikatif antara Penjual Buku-buku Bekas di Pasar Loak dan Pembeli}

Hasil observasi yang telah dilakukan, peneliti telah mengidentifikasi dua puluh data percakapan yang dikumpulkan dan lima belas dari data tersebut merupakan data percakapan dengan pembeli. Satu data di antaranya akan dijadikan sebagai bahan analisis. Pembeli adalah seseorang yang berminat berbelanja barang yang diinginkan. Interaksi jual beli di lapak buku bekas Pasar Loak ini, menggunakan pesan metacommunicative dalam usaha menentukan harga atau proses tawar-menawar. Menurut Adiwoso (1985:96) metacommunicative adalah pengetahuan budaya yang dimiliki oleh pembeli khususnya mengenai harga yang berlaku dalam proses transaksi jual beli. Dengan demikian, pola-pola komunikatif yang terbentuk dapat mengungkap makna-makna sosial budaya. Makna komunikasi tersebut terbentuk melalui proses interaksi antara penjual buku bekas dan pembeli berdasarkan barang dagangan yang akan dibeli.

Harga barang dagangan ditentukan oleh penjual buku bekas berdasarkan kualitas barang. Harga bisa menurun bergantung pada kemampuan berkomunikasi (communicative 
competence) ketika proses transaksi berlangsung. Potongan harga yang diberikan oleh penjual buku bekas bertujuan untuk menarik perhatian pembeli agar dapat bertemu kembali di interaksi berikutnya.

Data A.1 Pembeli buku bekas adalah mahasiswa IAIN Jember

1. Pembeli: [Datang dan kemudian bertanya tentang jenis buku yang dicari] Pak, ada buku Pembelajaran Bahasa Indonesia?

2. Penjual: Penerbitnya apa? Dari mana samean?

3. Pembeli: Dari IAIN, Pak.

4. Penjual: Ini Mbak, temennya semua ambil ini.

5. Pembeli: Berapa, Pak?

6. Penjual: 50 ribu, Mbak.

7. Pembeli: Iya Pak, ini.

Data percakapan A.1 di atas menunjukkan bahwa interaksi antara penjual dengan pembeli tidak disertai dengan proses tawar-menawar yang intensif karena pembeli sebelumnya sudah pernah mengetahui harga barang tersebut dari informasi temannya. Proses interaksi diawali dengan datangnya pembeli yang melihat-lihat barang kemudian dengan sikap tanggap penjual buku bekas melayani pembeli sebagai bentuk menarik perhatian (attention getter) pembeli.

Tindak tutur lokusi yang diucapkan oleh pembeli berupa pesan yang berisi tentang pertanyaan mencari barang yang diinginkan (di baris 1), tindakan tersebut dilakukan untuk mengonfirmasi barang yang dikehendaki ada atau tidak. Kemudian penjual menanggapi pertanyaan pembeli dengan jawaban berupa pesan yang berisi tentang jenis penerbit buku tersebut, dan dengan sikap tanggap penjual kemudian menanyakan dari mana (di baris 2), makna tersebut mengungkapkan bahwa penjual sudah berpengalaman dalam melayani pembeli yang sering datang.

Tindak tutur ilokusi yang diucapkan oleh penjual berupa pesan yang menginformasikan tentang barang yang dikehendaki pembeli (di baris 4), tindakan tersebut bertujuan untuk menarik minat pembeli. Kemudian pembeli memaknai tindakan penjual buku bekas tersebut dengan jawaban berisi pesan yang bertanya tentang harga barang tersebut (di baris 5) karena pembeli memang menginginkan barang atau buku tersebut. Selanjutnya, penjual mengkonfirmasikan harga buku tersebut (di baris 6) yang kemudian penjual membungkus buku yang pembeli sepakat dengan harga yang diberikan oleh penjual.

Dalam interaksi ini, penjual aktif mengarahkan interaksi dan pembeli pasif dalam menanggapi penjual buku bekas di pasar loak "Blok M" yang mengarah pada inti percakapan. Proses interaksi tersebut bertujuan untuk membangun hubungan sosial phatic communion, dapat membantu pembeli dalam menilai sikap tanggap dari pelayanan penjual buku bekas, sehingga nantinya pembeli dapat menentukan akan tetap menjadi pelanggan atau tidak bergantung pada kepuasan pembeli.

Dalam transaksi jual beli dengan pembeli, pelayanan yang diberikan oleh penjual buku bekas sangat cepat dan tempo interaksi yang digunakan oleh penjual sangat singkat. Urutan proses tindak komunikatif diawali dengan communicative competence, attention getter, untuk 
menarik perhatian pembeli dan untuk memelihara hubungan sosial (phatic communion). Secara implisit, tuturan perlokusi yang dilakukan penjual buku bekas sebagai upaya untuk menjalin hubungan baik dengan ungkapan memberikan perhatian khusus (di baris 2). Bahasa krama inggil yang diucapkan oleh penjual digunakan untuk menghormati seseorang, selain untuk penutup percakapan. Kesepakatan harga barang terjadi tidak disertai proses tawarmenawar antara penjual dan pembeli. Selanjutnya, percakapan berakhir dengan ungkapan rasa terimakasih. Interaksi dialogis tersebut mendukung tujuan utama, yaitu memperoleh barang yang diinginkan untuk memenuhi kebutuhan, (attention getter) untuk menarik perhatian pembeli untuk mewujudkan hubungan antarpersonal yang dapat membantu kerjasama ekonomi (jual beli) dalam jangka panjang. Jika hubungan tersebut dapat terjalin semakin erat, pembeli akan merasa puas (satisfy) dan akan tetap menjadi pelanggan.

Tema budaya dari data A.1 adalah dalam proses transaksi ekonomi antara penjual buku bekas dan pembeli yang menjalin ikatan sosio-emosional dalam rangka mempererat relasi dan saling menghormati merupakan bentuk untuk membantu kerjasama ekonomi jangka panjang. Kegiatan jual beli antara penjual dan pembeli dengan pemberian potongan harga secara terbuka mempunyai maksud tertentu. Hal ini dapat dilihat pada data di bawah ini.

Data A.2: Pembeli buku bekas

1.Pembeli: [Mendatangi lapak buku bekas, kemudian bertanya tentang jenis buku yang dikehendaki] Pak, ada buku seperti gambar ini?

2. Penjual: [Melihat gambar yang diberikan pembeli] Ada Mbak untuk anak SD kelas 6 ya? Penerbitnya Airlangga.

3. Pembeli: [tersenyum] Iya, Pak.

4. Penjual: [menyerahkan buku yang dikehendaki pembeli] Ini, Mbak.

5. Pembeli: Berapa, Pak?

6. Penjual: 25 ribu, Mbak.

7. Pembeli: Gak 15 ribu, Pak?

8. Penjual: Iya sudah, ambil Mbak.

Data percakapan A.2 antara penjual buku bekas dan pembeli di atas menunjukkan bahwa transaksi bersifat tidak ekonomi semata-mata. Proses interaksi diawali dengan datangnya pembeli yang memilih jenis barang kemudian pembeli menyampaikan pesan yang berisi tentang pertanyaan barang yang sedang dicari (di baris 1).

Tindak tutur lokusi yang diungkapkan oleh pembeli merupakan ungkapan pembeli bahwa pembeli sedang mencari jenis buku tersebut. Kemudian, penjual memaknai pesan yang disampaikan oleh pembeli dengan pesan rekonfirmasi tentang jenis buku yang sedang dikehendaki pembeli (di baris 2). Selanjutnya, pembeli menanggapi rekonfirmasi yang diberikan pelayan dengan tindak tutur ilokusi (di baris 3).

Kemudian penjual menunjukkan jenis barang yang dikehendaki oleh pembeli (di baris 4). Tindakan tersebut merupakan salah satu cara untuk menarik minat pembeli dengan cara melayani pembeli. Selanjutnya, pembeli memaknai tindakan penjual dengan menanyakan tentang harga buku tersebut (di baris 5). Tindakan tersebut dilakukan karena pembeli sebenarnya menghendaki jumlah barang menurut kemampuannya.

Penjual memaknai pernyataan pembeli dengan tindak tutur lokusi yang berisi pesan rekonfirmasi tentang harga buku tersebut (di baris 6). Tindakan tersebut bertujuan untuk 
menarik minat pembeli agar membeli barang tersebut. Kemudian, interaksi antara penjual buku bekas dan pembeli menunjukkan adanya tindak tutur illokusi dalam bentuk negosiasi secara timbal balik agar interaksi tetap terarah (di baris 7 sampai 8)

Kemudian, pelayan toko memberikan rekonfirmasi tentang harga barang dengan tindak tutur perlokusi (di baris 8). Tindakan tersebut dilakukan untuk mempengaruhi pembeli agar pembeli memiliki asumsi bahwa lapak buku bekas tersebut merupakan lapak dengan harga murah dan berkualitas bagus. Urutan tindak komunikatif (communicative act sequence), kerangka frame bergeser menuju pembicaraan tentang jenis warna barang, (attention getter) untuk menarik perhatian pembeli, dan memelihara hubungan interpersonal antara penjual dan pembeli. Beberapa gerakan (move) tuturan perlokusi berupa informasi tentang jumlah keseluruhan yang harus dibayar mendapat potongan harga (di baris 8). Tindakan tersebut dilakukan oleh pegawai toko dengan tujuan untuk menjalin hubungan ekonomi yang berkelanjutan.

Dalam skema penelitian sosial di atas terdapat delapan variasi struktur. Dari skema tersebut, interaksi penjual dan pembeli disertai proses tawar-menawar secara intensif. Hal ini menunjukkan bahwa pembeli mengetahui harga barang yang berlaku di pasar loak "Blok M". Interaksi timbal-balik terbangun untuk mendukung tujuan utama, yaitu memperoleh barang dagangan yang merupakan kebutuhan dan untuk menjalin hubungan interpersonal yang dapat membantu kerjasama ekonomi (jual beli) dalam jangka waktu panjang. Jika hubungan tersebut semakin erat, akan membantu proses transformasi pembeli kadang kala menjadi langganan. Berdasarkan data percakapan A.2 di atas, didapat suatu tema budaya dalam kesepakatan jual beli, yaitu penyerahan harga barang yang diberi potongan atau kortingan harga merupakan strategi ekonomi, yakni untuk menarik pembeli menjadi pelanggan, sehingga terbangun kerjasama ekonomi dalam jangka waktu panjang yang menguntungkan antara penjual dan pembeli. Dengan tidak adanya pengetahuan yang dimiliki, pesan metacomunicative akan berbeda jika jumlah dan harga barang sepenuhnya ditentukan penjual karena dalam lapak buku bekas menggunakan proses tawar-menawar. Hal ini dapat dilihat pada data di bawah ini.

Data A.3 Pembeli buku bekas.

1. Pembeli: [Melihat-lihat buku-buku] berapa ini, Pak?

2. Penjual: 30 ribu, Mas. Ambil berapa, Samean?

3. Pembeli: Satu, Pak.

4. Penjual: 25 ribu sudah, Mas.

5. Pembeli : Terimakasih, pak.

Data percakapan A.3 di atas memperlihatkan bahwa tindakan pembeli mendatangi lapak buku bekas dan melihat-lihat serta memilih barang merupakan tindakan yang paling umum dilakukan. Secara sadar atau tidak sadar, beberapa gerakan (move) itu berfungsi sebagai pembuka percakapan antara pembeli dan penjual buku bekas untuk menarik perhatian (attention getter).

Dalam interaksi ini, penjual aktif mengarahkan interaksi sesuai dengan kebutuhan yang diperlukan oleh konsumen. Tindak tutur lokusi diucapkan oleh pembeli dengan ungkapan 
pesan yang berisi pertanyaan tentang harga barang dan jumlah barang (di baris 1). Tindakan tersebut menandakan bahwa pembeli tidak mengetahui harga barang karena sebelumnya memang belum pernah belanja di lapak buku bekas tersebut. Tuturan illokusi yang diucapkan oleh penjual berupa rekonfirmasi tentang harga barang (di baris 2). Tindakan tersebut dilakukan oleh penjual buku bekas sebagai bentuk sikap tanggap untuk kelancaran transaksi jual beli barang. Selanjutnya, pembeli memaknai rekonfirmasi yang diberikan penjual dengan menyampaikan pesan bahwa ia membeli barang dengan jumlah yang ia kehendaki (di baris 3 ). Kemudian penjual menanggapi pesan yang disampaikan pembeli dengan tindak tutur perlokusi berupa informasi tentang harga barang dan memberikan potongan harga (di baris 4). Tindakan tersebut dilakukan oleh penjual untuk menginformasikan kepada pembeli dan untuk menjalin hubungan ekonomi (jual beli) jangka panjang yang berkelanjutan. Data percakapan di atas menunjukkan adanya interaksi percakapan minimal antara penjual buku bekas dan pembeli. Dengan kata lain, sifat transaksi jual beli hanya terbatas pada penawaran harga buku yang menggunakan komunikasi verbal untuk membangun adanya keakraban.

\section{SIMPULAN}

Dalam interaksi jual beli di pasar loak "Blok M" Jember, penjual aktif mengarahkan interaksi dan pembeli pasif dalam menanggapi yang mengarah pada inti percakapan. Dalam transaksi jual beli dengan pembeli, pelayanan yang diberikan oleh penjual buku bekas sangat cepat dan tempo interaksi yang digunakan oleh penjual sangat singkat. Tuturan perlokusi yang dilakukan penjual buku bekas dilakukan sebagai upaya untuk menjalin hubungan baik dengan pembeli. Jika hubungan tersebut dapat terjalin semakin erat, maka pembeli akan merasa puas (satisfy) dan akan tetap menjadi pelanggan.

Tema budaya dalam proses transaksi ekonomi antara penjual buku bekas dan pembeli adalah terjalinnya ikatan sosio-emosional dalam rangka mempererat relasi dan saling menghormati untuk membantu kerjasama ekonomi jangka panjang. Kegiatan jual beli antara penjual dan pembeli dengan pemberian potongan harga secara terbuka mempunyai maksud tertentu. Interaksi timbal-balik terbangun untuk mendukung tujuan utama, yaitu memperoleh barang dagangan yang merupakan kebutuhan dan untuk menjalin hubungan interpersonal yang dapat membantu kerjasama ekonomi (jual beli) dalam jangka waktu panjang. Tema budaya dalam kesepakatan jual beli tersebut adalah penyerahan harga barang yang diberi potongan harga merupakan strategi ekonomi, yakni untuk menarik pembeli menjadi pelanggan, sehingga terbangun kerjasama ekonomi dalam jangka waktu panjang yang menguntungkan antara penjual dan pembeli.

\section{DAFTAR PUSTAKA}

Adiwoso, S.R. 1985. "Interaksi Jual Beli dan Tindak Komunikasi di Tempat Belanja". Prisma. Jakarta: Prisma.

Afrizal. 2015. Metode Penelitian Kualitatif. Jakarta: Rajagrafindo Persada.

Bungin, B. 2007. Metode Penelitian Kualitatif. Jakarta: Raja Grafindo Persada.

Chaer, A. \& Agustina, L. 2010. Sosiolinguistik: Perkenalan Awal. Jakarta: Rineka Cipta.

Emzir. 2010. Metodologi Penelitian Kualitatif: Analisis Data. Jakarta: Rajawali Pers. 
Hamidi. 2010. Metode Penelitian Kualitatif. Malang: UMM Press.

Ibrahim, A.S. 1994. Panduan Penelitian Etnografi Komunikasi. Surabaya: Usaha Nasional.

Izzah, L. 2014. "Interaksi Jual Beli Hasil Tangkapan Nelayan di Weru Kompleks Kecamatan Paciran Kabupaten Lamongan (Suatu Tinjauan Etnografi Komunikasi)”. Skripsi. Fakultas Sastra Universitas Jember.

Kuswarno, Engkus. 2008. Metode Penelitian Komunikasi Etnografi Komunikasi: Suatu Pengantar dan Contoh Penelitiannya. Bandung: Widya Padjadjaran.

Littlejohn, S.W. \& Foss, K.A. 2009. Teori Komunikasi. Jakarta: Salemba Humanika.

Mangunsuwito, S.A. 2014. Kamus Lengkap Bahasa Jawa. Bandung: Yrama Widya.

Moleong, L.J. 2016. Metode Penelitian Kualitatif. Bandung: Remaja Rosdakarya.

Mukhtar. 2013. Metode Penelitian Deskriptif Kualitatif. Jakarta: GP Press Group.

Spradley, J.P. 1997. The Ethnographic Interview. New York: Holt, Rinehart and Winston.

Sugiyono. 2016. Metode Penelitian Kuantitatif, Kualitatif dan R\&D. Bandung: Alfabet.

Wibowo, R.P. 2015. "Pola Komunikasi antara Penjual dan Pembeli di Pasar Kalipait Kecamatan Tegal Dlimo Kabupaten Banyuwangi (Kajian Etnografi Komunikasi)." Skripsi. Fakultas Sastra Universitas Jember. 